Shumna T. Ye., Voznyi O. V., Zinchenko T. P., Kamyshnyi O. M. Frequency analysis of the ACTN3 gene polymorphism in children with isolated or combined orthodontic pathology with allergic rhinitis. Journal of Education, Health and Sport. 2020;10(7):41-55. eISSN 2391-8306. DOI http://dx.doi.org/10.12775/JEHS.2020.10.07.004

https://apcz.umk.pl/czasopisma/index.php/JEHS/article/view/JEHS.2020.10.07.004

https://zenodo.org/record/3937670

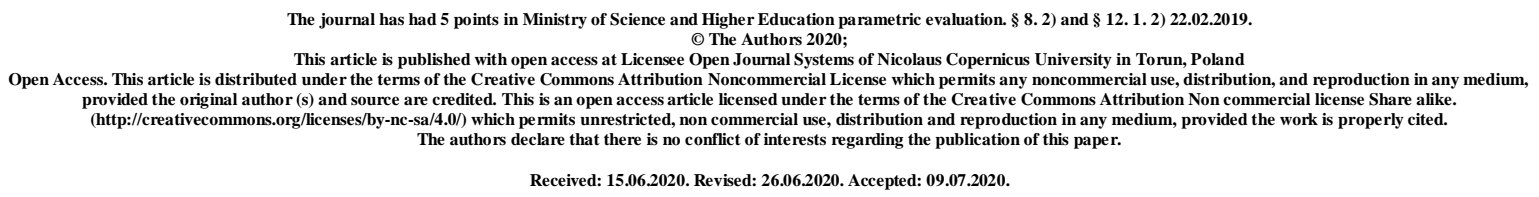

UDC616.314-06:616.211-002]-053.2:575.171.015.3]-07

\title{
FREQUENCY ANALYSIS OF THE ACTN3 GENE POLYMORPHISM IN CHILDREN WITH ISOLATED OR COMBINED ORTHODONTIC PATHOLOGY WITH ALLERGIC RHINITIS
}

\author{
T. Ye. Shumna, O. V. Voznyi, T. P. Zinchenko, O. M. Kamyshnyi
}

\section{Zaporizhzhia State Medical University, Zaporizhzhia, Ukraine}

Zaporizhzhia, Ukraine, 26 Maiakovskyi avenue, Zaporizhzhia, Ukraine, 69035

Shumna Tamila Yevhenivna, MD, PhD, Doctor of Medical Sciences, Professor of Department of Faculty Pediatrics, Tel .: +38097-854-18-09, +38093-284-90-75, e-mail: tshumnaya72@ gmail.com

Zinchenko Tetyana Petrivna, MD, Assistant of the Therapeutic, Orthopedic and Pediatric Dentistry Department, Tel .: +38067-304-70-31, e-mail: tzinchenko7@gmail.com

Voznyi Oleksandr Victorovych, MD, PhD, DrMedSci, Head of the Department of Therapeutic, Orthopedic and Pediatric Dentistry, Tel .: +38098-094-58-37, e-mail: voznyy.av@zsmu.zp.ua

Kamyshnyi Oleksandr Mykhalovych, MD, PhD, Doctor of Medical Sciences, Professor Department of Microbiology, Tel .: +38066-926-63-08, e-mail: alexkamyshnyi@gmail.com

\section{Abstract}

Purpose. Determination and frequency analysis of the ACTN3 gene (actinin, alpha 3) rs1815739 polymorphism, responsible for metabolism, strength and speed of muscle movement, including the maxillofacial apparatus, in children with distal occlusion and allergic rhinitis. 
Materials and Methods. To study the ACTN3 gene (rs1815739) polymorphism, the molecular and genetic study was conducted in 100 children aged 6 to 18 years. The 26 patients with distal bite and allergic rhinitis were included in the first study group; the second group consisted of 23 children with a distal bite; the third group included 30 children with allergic rhinitis and the fourth group was made up of 21 almost healthy children. All children did not have a statistically significant difference in sex and age. The molecular and genetic study was carried out in the Department of Molecular and Genetic Research of the Training Medical Laboratory Center in the Department of Microbiology of the Zaporizhia State Medical University, Zaporizhia. The obtained study results were analyzed using nonparametric methods of statistical analysis of the licensed software package «Statistica 6.1. RU». The population genetic analysis with the distribution of alleles and genotypes of the ACTN3 gene frequency is presented in accordance with the Hardy-Weinberg principle.

Results. Studying the distribution of allelic genes and genotypes of the ACN3 polymorphism (actinin, alpha 3) rs1815739 showed that among all examined children, the alpha actinin-3 protein was synthesized sufficiently in $36 \%$ of children with the homozygous C / C genotype, while in case of European population it was equal to $31 \%$; and insufficiently in $11 \%$ of those examined with the homozygous $\mathrm{T} / \mathrm{T}$ genotype (in the European population in $17.9 \%$ ); in a smaller amount - in $53 \%$ of children with the heterozygous $\mathrm{C} / \mathrm{T}$ genotype, which frequency corresponded to the European population $(51.1 \%)$. The genotypes had the following distribution in the study groups: in children with a combination of allergic and orthodontic pathology; with distal bite; with allergic rhinitis and in healthy children, respectively: homozygous C / C genotype - 38.46\%; 56.52\%; 33.33\%; 14.3\%; homozygous T / T genotype - $11.5 \% ; 8.7 \% ; 6.67 \% ; 19.05 \%$; heterozygous C / T genotype $-50 \% ; 34.78 \%$; $60 \% ; 66.67 \%$. In children with distal bite, the homozygous C / C genotype (rs1815739) of the gene coding alpha-actinin-3 protein synthesis was associated with the odds ratio $\mathrm{OR}=7.80$, CI [1.79 - 34.07], while in children with heterozygous genotype C / $\mathrm{T}$ the odds of being healthy was $\mathrm{OR}=3.75$, CI [1.08 - 13.07].

Conclusions. The dominant observation of the C / C genotype (rs1815739) of the gene coding alpha-actinin-3 protein synthesis in children with distal bite may indicate the role of muscle strength and their pressure on the dentition in the process of formation of children tooth-maxillary anomalies, which shall be taken into account when selecting individual treatment-and-preventive myogymnastics and apparatus treatment for such patients.

Key words: gene; polymorphism; alpha-actinin-3; distal bite; allergic rhinitis; children. 


\title{
АНАЛІЗ ЧАСТОТИ ЗУСТРІЧАСМОСТІ ПОЛІМОРФІЗМА ГЕНА АСТNЗ У ДІТЕЙ $З$ ОРТОДОНТИЧНОЮ ПАТОЛОГІЕЮ, ЯК ІЗОЛЬОВАНОЮ, ТАК І ПОСДНАНОЮ 3 АЛЕРГІЧНИМ РИНІТОМ
}

\author{
Т. Є. Шумна, О. В. Возний, Т. П. Зінченко, О. М. Камишний
}

Запорізький державний медичний університет, Запоріжжя, Україна

\section{Резюме}

Мета роботи. Визначення та проведення аналізу частоти зустрічаємості поліморфізму гена ACTN3 (actinin, alpha 3) rs1815739, що відповідає за метаболізм, силу та швидкість руху м'язів, в тому числі і щелепно-лицьового апарату, у дітей з дистальним прикусом і алергічним ринітом.

Матеріали та методи. Для вивчення поліморфізма гена ACTN3 (rs1815739) було проведено молекулярно-генетичне дослідження у 100 дітей від 6 до 18 років. До I групи спостереження увійшло 26 дітей з дистальним прикусом і алергічним ринітом; до II групи - 23 дитини тільки 3 дистальним прикусом; до III групи - 30 дітей тільки 3 алергічним ринітом; до IV групи - 21 практично здорова дитина. Всі діти не мали достовірних статистичних відмінностей за статтю та віком. Молекулярно-генетичне дослідження проводилось у відділі молекулярно-генетичних досліджень навчального медико-лабораторного центра на кафедрі мікробіології Запорізького державного медичного університету, м. Запоріжжя, на ампліфікаторі CFX96 ${ }^{\mathrm{TM}}$ Real-Time PCR Detection Systems («Bio-Rad laboratories, Inc.», USA) з виділенням ДНК із венозної крові за допомогою полімеразної ланцюгової реакції. Отримані результати дослідження були проаналізовані за допомогою непараметричних методів статистичного аналіза ліцензійного пакету програм «Statistica 6.1.RU». Популяційний генетичний аналіз 3 розподілом частот алелів та генотипів гена ACTN3 представлений згідно закону ХардіВайнберга.

Результати. Дослідження розподілу алельних генів та генотипів поліморфізму ACTN3 (actinin, alpha 3) rs1815739 показало, що серед всіх обстежених дітей білок альфа-актинін-3 синтезувався достатньо у $36 \%$ дітей з гомозиготним генотипом $\mathrm{C} / \mathrm{C}$ (вариабельність генотипу С/С в Свропі складає 31\%); недостатньо - у 11\% обстежених 3 гомозиготним генотипом Т/Т (в Свропі - 17.9\%); в меншій частці - у 53\% дітей 3 гетерозиготним генотипом $\mathrm{C} / \mathrm{T}$, частота якого співставлялась 3 показником 
європейської популяції (51.1\%). В групах спостереження, у дітей 3 поєднанням алергіченої та ортодонтичної патології; з дистальним прикусом; 3 алергічним ринітом та здорових, генотипи мали наступний розподіл: гомозиготний генотип $\mathrm{C} / \mathrm{C}-38.46 \%$; $56.52 \% ; 33.33 \% ; 14.3 \%$; гомозиготний генотип Т/Т - 11.5\%; 8.7\%; 6.67\%;19.05\%; гетерозиготний генотип С/Т-50\%; 34.78\%; 60\%; 66.67\%. У дітей 3 дистальним прикусом, гомозиготний генотип C/C (rs1815739) гена, що кодує синтез білка альфаактиніна-3 асоціювався з відношенням шансів $\mathrm{OR}=7.80$, CI [1.79 - 34.07], в той час як для дітей з гетерозиготним генотипом $\mathrm{C} / \mathrm{T}$ шанс бути здоровими склав $\mathrm{OR}=3.75, \mathrm{CI}$ [1.08-13.07].

Висновок. Домінуючий генотип С/C (rs1815739) гена, що кодує синтез білка альфа-актиніна-3 у дітей з дистальним прикусом може свідчити про значення сили м'язів та їх тиску на зубні ряди при формуванні зубо-щелепних аномалій у дітей, що необхідно враховувати при призначенні індивідуальної лікувально-профілактичної міогімнастики та апаратного лікування у таких пацієнтів.

Ключові слова: ген; поліморфізм; альфа-актинін-3; дистальний прикус; алергічнй риніт; діти.

\title{
АНАЛИЗ ЧАСТОТЫ ВСТРЕЧАЕМОСТИ ПОЛИМОРФИЗМА ГЕНА АСТNЗ У ДЕТЕЙ С ОРТОДОНТИЧЕСКОЙ ПАТОЛОГИЕЙ, КАК ИЗОЛИРОВАННОЙ, ТАК И СОЧЕТАЮЩЕЙСЯ С АЛЛЕРГИЧЕСКИМ РИНИТОМ
}

\author{
Т. Е. Шумная, А. В. Возный, Т. П. Зинченко, А. М. Камышный
}

Запорожский государственный медицинский университет, Запорожье, Украина

\section{Резюме}

Цель работы. Определление и проведение анализа частоты встречаемости полиморфизма гена ACTN3 (actinin, alpha 3) rs1815739, котрый отвечает за метаболизм, силу и скорость движения мышц, в том числе и челюстно-лицевого аппарата, у детей с дистальным прикусом и аллергическим ринитом.

Материалы и методы. Для изучения полиморфизма гена ACTN3 (rs1815739) было проведено молекулярно-генетическое исследование у 100 детей от 6 до 18 лет. В I группу наблюдения вошло 26 детей с дистальным прикусом и аллергическим ринитом; во II группу - 23 ребенка только с дистальным прикусом; в III группу - 30 детей только 
с аллергическим ринитом; в IV группу - 21 практически здоровых детей. Все дети не имели достоверных статистических отличий по полу и возрасту. Молекулярногенетическое исследование проводилось в отделе молекулярно-генетических исследований ученого медико-лабораторного центра на кафедре микробиологии Запорожского государственного медицинского университета, г. Запорожье, на амплификаторе CFX96 ${ }^{\mathrm{TM}}$ Real-Time PCR Detection Systems («Bio-Rad laboratories, Inc.», USA) с выделением ДНК из венозной крови при помощи полимеразной цепной реакции. Полученные результаты исследования были проанализированы при помощи непараметрических методов статистического анализа лицензионного пакета программ «Statistica 6.1. RU». Популяционный генетический анализ с распределением частот аллелей и генотипов гена ACTN3 представлен согласно закону Харди-Вайнберга.

Результаты. Изучение распределения аллельных генов и генотипов полиморфизма ACTN3 (actinin, alpha 3) rs1815739 показало, что среди всех обследованных детей белок альфа-актинина-3 синтезировался достаточно у $36 \%$ детей с гомозиготным генотипом $\mathrm{C} / \mathrm{C}$ (вариабельность генотипа $\mathrm{C} / \mathrm{C}$ в в Европе составляет $31 \%$ ); недостаточно - у 11\% обследованных с гомозиготным генотипом Т/Т (в Европе $17.9 \%$ ); в меньшем количестве - у 53\% детей с гетерозиготным генотипом C/T, частота которого согласовывалась с показателем европейской популяции (51.1\%). В группах наблюдения, у детей с сочетанием аллергической и ортодонтической патологии; с дистальным прикусом; с аллергическим ринитом и здоровых, генотипы имели следующее распределение: гомозиготный генотип С/C - 38.46\%; 56.52\%; 33.33\%; $14.3 \%$; гомозиготный генотип Т/T - 11.5\%; 8.7\%; 6.67\%;19.05\%; гетерозиготный генотип С/Т-50\%; 34.78\%; 60\%; 66.67\%. У детей с дистальным прикусом, гомозиготный генотип C/C (rs1815739) гена, кодирующего синтез белка альфаактинина-3 асоциировался с отношением шансов $\mathrm{OR}=7.80$, CI [1.79 - 34.07], в то время как для детей с гетерозиготным генотипом C/T шанс быть здоровым составил OR $=3.75$, CI $[1.08-13.07]$.

Выводы. Доминирующий генотип С/C (rs1815739) гена, кодирующий синтез белка альфа-актинина-3 у детей с дистальным прикусом может свидетельствовать о значении силы мышц и их давлении на зубные ряды при формировании зубочелюстных аномалий у детей, что необходимо учитывать при подборе индивидуальной лечебно-профилактической миогимнастики и аппаратного лечения у таких пациентов.

Ключевые слова: ген; полиморфизм; альфа-актинин-3; дистальний прикус; аллергический ринит; дети. 


\section{Introduction}

Nowadays as well as in the 30 s of the last century, the heated discussions have been held on the feasibility of the genetic studies. However, despite the controversial views of the scientists, the study of genetic aspects of the disease development will allow determining the risk of developing of a particular pathology and make it possible to timely take preventive measures to preclude its development. The genotype is characterized by phenotypic external features, including face features, which may be both due to heredity and the presence of orthodontic pathology with or without disorders of nasal breathing, most often of allergic genesis. Thus, to date the distal bite is registered in $1 / 3-1 / 2$ part of the examined children, and one to four children from ten suffer allergic rhinitis [1,2]. It is known that the development of masticatory and mimic muscles, the functional activity of the muscles of the maxillofacial apparatus, the myofunctional harmful habits of the child also affect the formation of orthodontic pathology, and special exercises for masticatory and mimic muscles are attributed to the prevention of abnormal occlusion at an early age in children [3]. Thus, in order to normalize muscle strength to prevent the development of occlusion anomalies or even to correct them, the muscles of the mouth, masticatory muscles, temporal and wing-palatal muscles are to be trained. In this case, the myogymnastics, aimed at performing exercises with multiple contractions of the muscles leads to thickening of the muscle fibers and increases their mass, especially strengthening the colonic muscle of the mouth and the muscles that protrude the lower jaw [3]. But the effectiveness of these exercises may depend not only on the professionalism of the physician who prescribes myogymnastics and diligence of the patient performing it, but also the presence or absence of alpha-actinin-3 protein synthesized in muscle fibers and responsible for metabolism, strength and muscle contraction speed and coded by the ACTN3 gene, which is located on the long section of the 11th chromosome $[4,5]$. Therefore, the effectiveness in achieving a positive preventive or therapeutic effect from prescribed muscle exercises during orthodontic pathology may depend on presence or absence of alpha-actinin-3 protein in the muscle of children. At the same time, the polymorphism of the ACTN3 gene may be one of the causes of metabolic disorders and decrease in the strength and speed of muscle movements, which will limit the ability to achieve positive therapeutic and preventive results from the appointment of myogymnastics.

Consequently, the molecular and genetic studies with the determination of ACTN3 gene polymorphism may be useful both for further understanding of the causes of distal bit and for predicting the effectiveness of therapeutic and preventive measures in conducting 
special exercises for masticatory and mimic muscles in children, both with isolated orthodontic and with comorbid pathology.

The presented research is a fragment of the scientific and research work of Faculty Pediatrics Department of Zaporizhia State Medical University: "Optimization of differential diagnostics and treatment of allergic and other diseases in children of different ages" (state registration number - 0118U004254), 2018-2022 years.

\section{Purpose}

Determination and frequency analysis of the ACTN3 gene (actinin, alpha 3) rs1815739 polymorphism, responsible for metabolism, strength and speed of muscle movement, including the maxillofacial apparatus, in children with distal occlusion and allergic rhinitis.

\section{Materials and Methods}

To study the ACTN3 gene (actinin, alpha 3) rs1815739 polymorphism, the molecular and genetic study was conducted in 100 children aged 6 to 18 years. The 26 patients with distal bite and allergic rhinitis were included in the first study group; the second group consisted of 23 children with a distal bite; the third group included 30 children with allergic rhinitis and the fourth group was made up of 21 almost healthy children. All children did not have a statistically significant difference in sex and age. The molecular and genetic study was carried out in the Department of Molecular and Genetic Research of the Training Medical Laboratory Center in the Department of Microbiology of the Zaporizhia State Medical University, Zaporizhia, on the CFX96 ${ }^{\mathrm{TM}}$ Real-Time PCR Detection Systems (Bio-Rad laboratories, Inc., USA) amplifier with the release of DNA from venous blood through a polymerase chain reaction (Head of the Department of Molecular and Genetic Research of the Training Medical Laboratory Center of the Zaporizhia State Medical University - the Head of the Department of Microbiology, Doctor of Medicine, Professor O.M. Kamyshnyi).

The obtained study results were analyzed using non-parametric methods of statistical analysis of the licensed software package «Statistica 10.RU» (non-parametric statistical method " $2 \times 2$ Table"; odds ratio (OR) with the detection of the confidence interval (CI) by the Woolf method). When comparing the indicators in each group of children, the differences p $<0.05$ were considered statistically significant. To evaluate the feature diagnostic significance the following indicators as sensitivity, specificity, accuracy and predictive value of positive and negative results were determined [6]. The population genetic analysis with the distribution of alleles and genotypes of the ACTN3 gene frequency is presented in accordance with the Hardy-Weinberg principle [5]. 


\section{Results}

The study of the ACCT3 gene (actinin, alpha 3) rs1815739 polymorphism showed that in general the heterozygous C / T genotype was recorded in 53\% (53/100) of 100 children examined. The homozygous genotypes occurred reliably less frequently, namely, the $\mathrm{C} / \mathrm{C}$ genotype - in 36\% (36/100) cases $(\mathrm{p}<0.05)$ and least rarely the $\mathrm{T} / \mathrm{T}$ genotype - in $11 \%$ $(11 / 100)$ of children, as when compared with the frequency of occurrence of C / T genotype $(\mathrm{p}<0.05)$ and with the frequency of $\mathrm{C} / \mathrm{C}$ genotype $(\mathrm{p}<0.05)$. We compared these data with the results of the dbSNP database of the US National Center for Biotechnological Information [7]. It may be said that the frequency of the heterozygous C / T genotype in our studies was close to the frequency of occurrence in AMR (Ad Mixed American) and CHS (Southern Han Chinese) populations, in which it was equal to $53.3 \%$. At the same time, its lowest frequency (16.2\%) was recorded in LWK (Luhya in Webuye, Kenya) and the highest frequency (59.2\%) - in GIH (Gujarati Indian from Houston, Texas); and in the European population the C / T genotype was $51.1 \%$. Our data on the $\mathrm{C} / \mathrm{C}$ genotype approached the frequency of occurrence (35\%) of the homozygous C / C genotype in CHB (Han Chinese in Beijing, China), while the variability of this genotype in populations ranges from 9.8\% in STU (Sri Lankan Tamil from the UK) to $83.8 \%$ in LWK (Luhya in Webuye, Kenya), and in Europe it is $31 \%$. As for the homozygous $\mathrm{T} / \mathrm{T}$ genotype, the results of our studies (11\%) approached the frequency of occurrence $(13.1 \%)$ of this genotype in FIN (Finnish in Finland), while its variability varies from $0.5 \%$ in AFR (African) to 55, 3\% in PEL (Peruvians from Lima, Peru) and in Europe is was recorded with a population frequency of $17.9 \%$ [7].

The analysis of the allele distribution in all examined children showed that the frequency of allelic $\mathrm{C}$ gene occurrence was $62.5 \%$ and the $\mathrm{T}$ allele occurrence - $37.5 \%$, $\mathrm{p}<0.05$. Our indicators for the frequency of $\mathrm{C}$ allele are close to the data characterizing the population of CHS (Southern Han Chinese) - 60\% and CHB (Han Chinese in Beijing, China) - 63.4\%, and regarding the frequency of the T allele - FIN (Finnish in Finland) - 34.3\%, KHV (Kinh in Ho Chi Minh City, Vietnam) - 40.9\%. In the European population, the frequency of the $\mathrm{C}$ and $\mathrm{T}$ allele was $56.6 \%$ and $43.4 \%$, respectively [7].

We also analyzed the frequency of occurrence of the allelic genes and genotypes of the ACTN3 gene (rs1815739) polymorphism in children from the 1st, $2^{\text {nd }}$ and 3rd study groups and in healthy children. Thus, when studying the ACTN3 gene polymorphism (rs1815739) in the $1^{\text {st }}$ group I of children with combined orthodontic and allergic pathology, the homozygous $\mathrm{C} / \mathrm{C}$ genotype was recorded in $38.46 \%$ (10/26) cases and the heterozygous C / T genotype in 
$50 \%$ (13/26) cases, that is significantly more often in comparison with the homozygous $\mathrm{T} / \mathrm{T}$ genotype, which was detected only in $11.5 \%(3 / 26)$ of cases $(\mathrm{p}<0.05$, respectively).

In children with distal bite (the $2^{\text {nd }}$ study group) among the homozygous genotypes, the C / C genotype prevailed, which was recorded in 56.52\% (13/23) children versus $8.7 \%$ (2/23) patients with $\mathrm{T} / \mathrm{T}$ genotype, $\mathrm{p}<0.05$. The heterozygous $\mathrm{C} / \mathrm{T}$ genotype was diagnosed in $34.78 \%(8 / 23)$ of the patients and as well as in the previous group significantly more often in comparison with the homozygous $\mathrm{T} / \mathrm{T}$ genotype, $\mathrm{p}<0.05$.

In children without orthodontic pathology, but with nasal breathing defects due to allergic rhinitis from the $3^{\text {rd }}$ study group the heterozygous $\mathrm{C} / \mathrm{T}$ genotype was significantly more frequent, which frequency made 60\% (18/30) against the homozygous C / C genotypes $33.33 \%$ (10/30), $\mathrm{p}<0.05$ and $\mathrm{T} / \mathrm{T}$ genotypes $-6.67 \%(2 / 30), \mathrm{p}<0.05$. But among the presented homozygous genotypes, the $\mathrm{C} / \mathrm{C}$ genotype reliably prevailed than the $\mathrm{T} / \mathrm{T}$ one, $\mathrm{p}<0.05$, respectively.

In healthy children of the $4^{\text {th }}$ control group, the heterozygous variant of the $\mathrm{C} / \mathrm{T}$ genotype was recorded with a frequency of $66.67 \%$ (14/21), that is significantly more often than the homozygous $\mathrm{C} / \mathrm{C}$ and $\mathrm{T} / \mathrm{T}$ genotypes, which occurred with a frequency of $14.3 \%$ (3/ 21) and $19.05 \%(4 / 21)$.

The comparative characteristics of the frequency of occurrence of each of the genotypes of the ACTN3 gene (rs1815739), both within each of the examined groups of children and depending on the presence or absence of orthodontic and / or allergic pathology in the examined children is presented in the Figure 1.

Thus, the frequency of occurrence of the $\mathrm{T} / \mathrm{T}$ genotype did not have significant differences in children of different study groups. But in patients with orthodontic pathology in the $2^{\text {nd }}$ study group the homozygous $\mathrm{C} / \mathrm{C}$ genotype was recorded significantly more often and the heterozygous $\mathrm{C} / \mathrm{T}$ genotype was less common than in almost healthy children from the 4th group: $56.52 \%$ vs. $14.3 \%, \mathrm{p}<0.05$ and $34.78 \%$ versus $66.67 \%, \mathrm{p}<0.05$, respectively.

The frequency of occurrence of the ACTN3 gene (rs1815739) alleles according to the Hardy-Weinberg equilibrium law of inheritance is presented in Fig. 2. It showed that children with orthodontic pathology were significantly more likely to be carriers of the $\mathrm{C}$ allele (73.9\%) and less often $\mathrm{T}(26.1 \%)$ allele, while in healthy individuals the distribution of $\mathrm{C}$ and $\mathrm{T}$ alleles was almost the same and amounted to $47.6 \%$ and $52.4 \%$, respectively. Therefore, the relation of the $\mathrm{C}$ allele with the distal bite in children when compared with a healthy group was characterized by the odds ratio $\mathrm{OR}=3.12$, CI [1.27 - 7.62] (Table 1). 


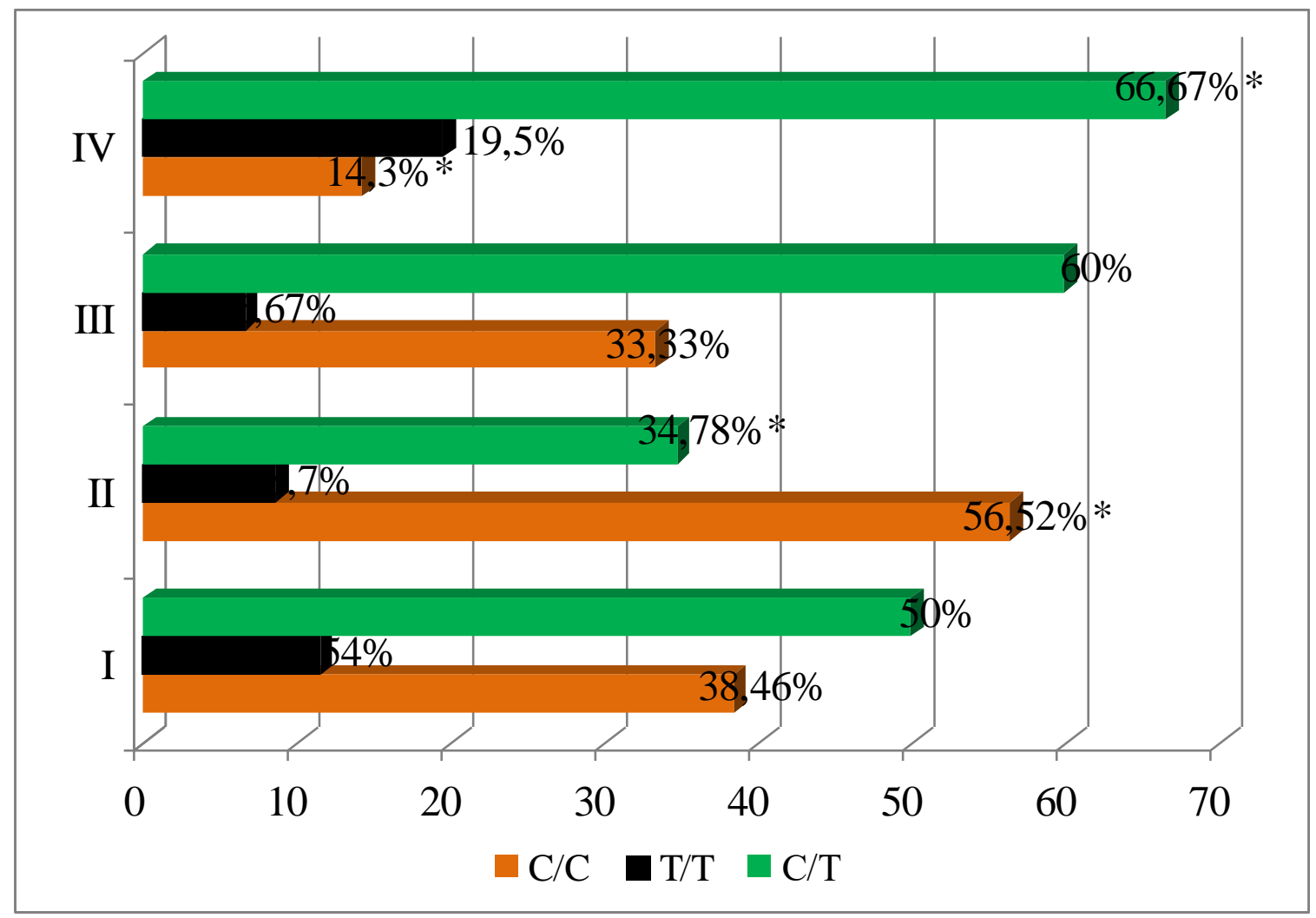

Fig.1. Characteristics of genotypes of the ACTN3 (rs1815739) gene in children ${ }^{*}-\mathrm{p}<0.05$ in comparison with the corresponding II and IV groups of children; c/c;T/T reliability in group of children, $\mathrm{p}<0.05)$.

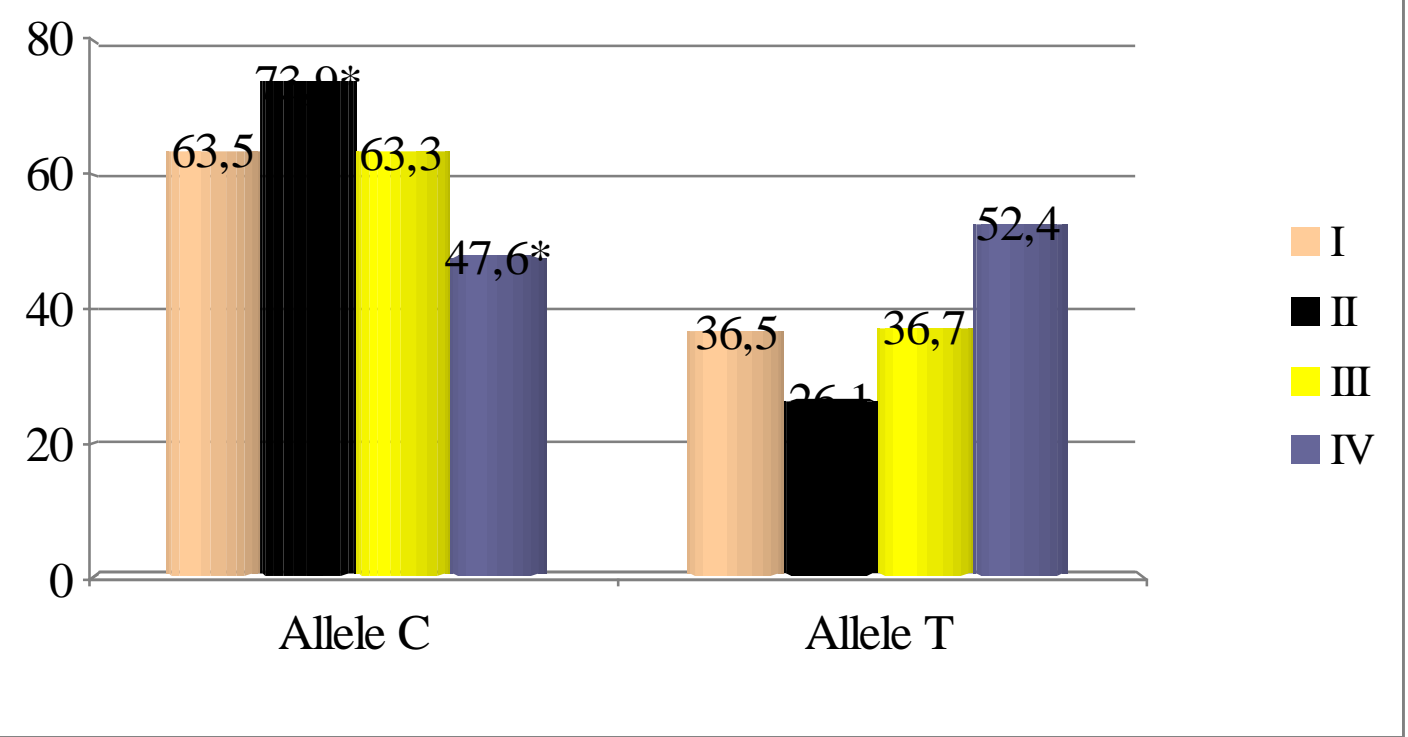

Fig.2. Frequency of occurrence of alleles of of genotypes of the ACTN3 (rs1815739) gene in children $\left(^{*}-\mathrm{p}<0.05\right.$ in comparison with the II and IV groups of children). 
Table 1 - Characteristics of the distribution of allelic genes in children II and IV groups according to the data of multiplicative models of inheritance (chi-square test, $\mathrm{df}=1$ )

\begin{tabular}{|c|c|c|c|c|c|c|}
\hline \multirow{2}{*}{ Allelic } & II & IV & \multirow{2}{*}{$\chi^{2}$} & $p$ & OR & $95 \%$ CI \\
\cline { 2 - 3 } & $\mathrm{n}=23$ & $\mathrm{n}=21$ & & & & \\
\hline $\mathrm{C}$ & 0.739 & 0.476 & \multirow{2}{*}{6.40} & 0.01 & 3.12 & $1.27-7.62$ \\
\cline { 7 - 7 } & 0.261 & 0.524 & & & 0.32 & $0.13-0.78$ \\
\hline
\end{tabular}

Also in children with distal bite the homozygous C / C genotype (rs1815739) of the gene coding alpha-actinin-3 protein synthesis was associated with the odds ratio $\mathrm{OR}=7.80$, CI [1.79 - 34.07] (Table 2). At the same time, children with the heterozygous $\mathrm{C} / \mathrm{T}$ genotype and homozygous T / T genotypes (rs1815739) often did not have distal bite (Table 3).

Table 2 - General model of inheritance in children II and IV groups (chi-square test, $\mathrm{df}=2$ )

\begin{tabular}{|c|c|c|c|c|c|c|}
\hline \multirow{2}{*}{ Genotypes } & II & IV & \multirow{2}{*}{$\chi^{2}$} & $p$ & OR & 95\% CI \\
\cline { 2 - 3 } & $\mathrm{n}=23$ & $\mathrm{n}=21$ & & & & \\
\hline $\mathrm{C} / \mathrm{C}$ & 0.565 & 0.143 & \multirow{3}{*}{8.48} & \multirow{2}{*}{0.01} & 7.80 & $1.79-34.07$ \\
\hline $\mathrm{C} / \mathrm{T}$ & 0.348 & 0.667 & 0.27 & $0.08-0.93$ \\
\hline $\mathrm{T} / \mathrm{T} / \mathrm{T}$ & 0.087 & 0.190 & & & 0.40 & $0.07-2.48$ \\
\hline
\end{tabular}

Table 3 - A recessive model of inheritance in children II and IV groups (chi-square test, $\mathrm{df}=1$ )

\begin{tabular}{|c|c|c|c|c|c|c|}
\hline \multirow{2}{*}{ Genotypes } & II & IV & \multirow{2}{*}{$\chi^{2}$} & $p$ & OR & 95\% CI \\
\cline { 2 - 3 } & $\mathrm{n}=23$ & $\mathrm{n}=21$ & & & & \\
\hline $\mathrm{C} / \mathrm{C}$ & 0.565 & 0.143 & \multirow{2}{*}{8.46} & 0.004 & 7.80 & $1.79-34.07$ \\
\cline { 6 - 7 } $\mathrm{C} / \mathrm{T}+\mathrm{T} / \mathrm{T}$ & 0.435 & 0.857 & & & 0.13 & $0.03-0.56$ \\
\hline
\end{tabular}

This made it possible to determine the prognostic associative significance of the homozygous C / C genotype (rs1815739) with orthodontic pathologies in children with the specificity $-85.7 \%$; sensitivity $-56.52 \%$, accuracy $-70.45 \%$, predictive value for a positive result $-81.25 \%$ and the predictive value for a negative result $-64.29 \%$. Consequently, on the one hand, the molecular and genetic study determining the polymorphism of the ACTN3 gene (rs1815739) coding alpha actinin-3 protein synthesis in children can be recommended to 
determine the risk of orthodontic pathology, and on the other, it will allow to recommend the preventive measures aimed at substantiation of the purposefulness to prescribe myogymnastics or individual selection of therapeutic and gymnastic exercises and apparatus methods of treatment.

\section{Discussion}

As of today it is known that changes in the muscle tone of the perioral area, occiput and neck are the root cause of the occurrence of tooth-maxillary anomalies. It may be supported by an underdevelopment of the orbicular muscles of the mouth and / or facial muscles, and vice versa, strong pressure of the cheeks on the lateral parts of the dentition or pressure of the lips and tongue on the dentition, which violates their proper forging and retards the growth of the jaw [3]. But there are almost no data on the genetic aspects of the study of muscle strength in children with the detection of the polymorphism of the ACTN3 (rs1815739) gene, coding the synthesis of the alpha-actinin-3 protein. To date, it has been proven that the ACTN3 R577X genotype is a modifier of the clinical phenotype in patients with Duchenne muscular dystrophy [8]. The references also describe the results of the studies dedicated to searching the genetic markers that characterize muscle strength and endurance in sportsmen $[9,10,11,12]$. Therefore, the polymorphism of the ACTN3 gene was suggested to be taken into account when selecting exercises and trainings [13, 14, 15]. The interrelation of the ACTN3 polymorphism with the phenotype of muscle function defect, bone tissue mineral density and metabolic disorders in elderly people, including women, was also studied, followed by the selection of exercises to maintain their health state $[13,16]$. According to the results of the analyzed studies, the dominant detection of the C / C genotype (rs1815739) of the gene coding alpha-actinin-3 protein synthesis in children with distal bite may indicate the role of muscle strength and their pressure on the dentition in the process of formation of children tooth-maxillary anomalies, which shall be taken into account when selecting individual treatment-and-preventive myogymnastics and apparatus treatment for such patients.

\section{Conclusions}

1. Studying the distribution of allelic genes and genotypes of the ACN3 polymorphism (actinin, alpha 3) rs1815739 showed that among all examined children, the alpha actinin-3 protein was synthesized sufficiently in $36 \%$ of children with the homozygous $\mathrm{C} / \mathrm{C}$ genotype, while in case of European population it was equal to $31 \%$; and insufficiently in $11 \%$ of those examined with the homozygous $\mathrm{T} / \mathrm{T}$ genotype (in the European population - 
in $17.9 \%$ ); in a smaller amount - in $53 \%$ of children with the heterozygous $\mathrm{C} / \mathrm{T}$ genotype, which frequency corresponded to the European population $(51.1 \%)$.

2. The genotypes had the following distribution in the study groups: in children with a combination of allergic and orthodontic pathology; with distal bite; with allergic rhinitis and in healthy children, respectively: homozygous C / C genotype $-38.46 \%$; 56.52\%; $33.33 \%$; $14.3 \%$; homozygous T / T genotype $-11.5 \% ; 8.7 \% ; 6.67 \% ; 19.05 \%$; heterozygous C / T genotype $-50 \% ; 34.78 \% ; 60 \% ; 66.67 \%$.

3. In children with distal bite, the homozygous C / C genotype (rs1815739) of the gene coding alpha-actinin-3 protein synthesis was associated with the odds ratio $\mathrm{OR}=7.80$, CI [1.79 - 34.07].

4. The dominant observation of the C / C genotype (rs1815739) of the gene coding alpha-actinin-3 protein synthesis in children with distal bite may indicate the role of muscle strength and their pressure on the dentition in the process of formation of children tooth-maxillary anomalies, which shall be taken into account when selecting individual treatment-and-preventive myogymnastics and apparatus treatment for such patients.

5. The children with allergic rhinitis and combined orthodontic pathology with allergic rhinitis, the homozygous C / T and T / T genotype (rs1815739) of the gene ACTN3, treat allergic rhinitis for ensure nasal breathing and prevent the development of facial skeleton deformities with a distal bite.

\section{Prospects for further researches}

In the future, we are planning to continue studying the distribution patterns for allelic genes and genotypes of the ACTN3 polymorphism for SNP (rs1815739) in more children and for IL-4 gene polymorphism for SNP (rs2243250) in patients with nasal obstruction of allergic genesis, distal bite and combined allergic and orthodontic pathology with the performance of the results comparative characteristics.

\section{References}

1. VSN. V. (2017). The Prevention of Malocclusions. Journal of Dental Sciences, 2(4). https://doi.org/10.23880/oajds-16000140

2. Brożek, J. L., Bousquet, J., Baena-Cagnani, C. E., Bonini, S., Canonica, G. W., Casale, T. B., van Wijk, R. G., Ohta, K., Zuberbier, T., \& Schünemann, H. J. (2010). Allergic Rhinitis and its Impact on Asthma (ARIA) guidelines: 2010 Revision. Journal of Allergy and Clinical Immunology, 126(3), 466-476. https://doi.org/10.1016/j.jaci.2010.06.047

3. Flis, P.S. (2007). Ortodontiya, Vinnytsia, 312. 
4. Hubskyi, Iu.I., Nizhenkovska, I.V., Korda, M.M. et al. (2016). Biolohichna i bioorhanichna khimiia, pidruchnyk. Kn. 2., K, 544.

5. Mandel, B.R. (2016). Osnovы sovremennoi henetyky: uch. Posobye dlia uchashchykhsia vыsshykh uchebnыkh zavedenyi, M, 334.

6. Rebrova, O.Yu. (2006). Statisticheskiy analiz meditsinskih dannyih. Primenenie paketa prikladnyih programm STATISTICA, M, 312.

7. National Center for Biotechnology information, dbSNP database. http://www.ncbi.nim.nih.gov/SNP/.

8. Marshall, W. Hogarth, Peter, J. Houweling, Kristen, C. Thomas, Heather, GordishDressman, Luca, Bello, Pegoraro, Elena, et. al. (2017). Evidence for ACTN3 as a genetic modifier of Duchenne muscular dystrophy. Nature Communications., 8. https://doi: 10.1038/ncomms14143.

9. Papadimitriou, I. D., Lockey, S. J., Voisin, S., Herbert, A. J., Garton, F., Houweling, P. J., Cieszczyk, P., Maciejewska-Skrendo, A., Sawczuk, M., Massidda, M., Calò, C. M., Astratenkova, I. V., Kouvatsi, A., Druzhevskaya, A. M., Jacques, M., Ahmetov, I. I., Stebbings, G. K., Heffernan, S., Day, S. H., ... Eynon, N. (2018). No association between ACTN3 R577X and ACE I/D polymorphisms and endurance running times in 698 Caucasian athletes. BMC Genomics, 19. https://doi.org/10.1186/s12864-017-4412-0

10. Eynon, N., Ruiz, J. R., Oliveira, J., Duarte, J. A., Birk, R., \& Lucia, A. (2011). Genes and elite athletes: a roadmap for future research. The Journal of Physiology, 589(13), 3063-3070. https://doi.org/10.1113/jphysiol.2011.207035

11. Del Coso, J., Valero, M., Salinero, J. J., Lara, B., Gallo-Salazar, C., \& Areces, F. (2017). Optimum polygenic profile to resist exertional rhabdomyolysis during a marathon. PLOS ONE, 12(3), e0172965. https://doi.org/10.1371/journal.pone.0172965

12. Gineviciene, V., Jakaitiene, A., Aksenov, M., Aksenova, A., Druzhevskaya, A., Astratenkova, I., Egorova, E., Gabdrakhmanova, L., Tubelis, L., Kucinskas, V., \& Utkus, A. (2016). Association analysis of ACE, ACTN3 and PPARGC1A gene polymorphisms in two cohorts of European strength and power athletes. Biology of Sport, 33(3), 199-206. https://doi.org/10.5604/20831862.1201051

13. Pickering, C., \& Kiely, J. (2017). ACTN3: More than Just a Gene for Speed. Frontiers in Physiology, 8. https://doi.org/10.3389/fphys.2017.01080

14. Baumert, P., Lake, M. J., Stewart, C. E., Drust, B., \& Erskine, R. M. (2016). Genetic variation and exercise-induced muscle damage: implications for athletic performance, 
injury and ageing. European Journal of Applied Physiology, 116(9), 1595-1625. https://doi.org/10.1007/s00421-016-3411-1

15. Jones, N., Kiely, J., Suraci, B., Collins, D., de Lorenzo, D., Pickering, C., \& Grimaldi, K. (2016). A genetic-based algorithm for personalized resistance-training. Biology of Sport, 33(2), 117-126. https://doi.org/10.5604/20831862.1198210

16. Min, S.-K., Lim, S.-T., \& Kim, C.-S. (2016). Association of ACTN3 polymorphisms with BMD, and physical fitness of elderly women. Journal of Physical Therapy Science, 28(10), 2731-2736. https://doi.org/10.1589/jpts.28.2731 